\title{
ON THE DETERMINATION OF SOIL $\mathrm{pH}$
}

\author{
Ritva Ryti \\ University of Helsinki, Department of Agricultural Chemistry, Pihlajamäki
}

Received December 1, 1964

Soil $\mathrm{pH}$ values are considered essential knowledge for understanding and interpreting several other soil properties. Yet the concept of soil $\mathrm{pH}$ remains rather vague and the different methods for actual measurement indicate a lack of a definite goal. For purposes of agricultural practice, the interpreting of $\mathrm{pH}$ values has proved difficult.

The history of soil acidity research, as reviewed by JENNY (2), shows that with the development of theoretical ideas also new empirical methods are being developed for characterizing soil acidity. Among these attempts, the potentiometric determination of soil $\mathrm{pH}$ has reasonably retained its validity in spite of its weaknesses. At present the soil $\mathrm{pH}$ is recognised as one of the many interdependent variables of the soil, and used accordingly.

For the routine measurement of soil $\mathrm{pH}$ the procedure using $0.01 \mathrm{M} \mathrm{CaCl}_{2}$ developed by SCHOFIELD and TAYLOR (9) has a firm theoretical basis, originally suggested by TERÄSVUORI (12). For acid soils containing calcium as the dominant exchangeable cation the ion activity ratio $\mathrm{aH}^{+} / \sqrt{\mathrm{aCa}^{2+}}$ is claimed to be constant on the adsorption spheres of the soil particles and in the outer solution of an equilibrium suspension and therefore characteristic of the suspension. As $0.01 \mathrm{M} \mathrm{CaCl}_{2}$ approximates the electrolyte concentration of the soil solution, introducing it into the system causes least disturbance to the soil and yet provides relatively constant ionic strength for obtaining comparable results from different soils. The method has been employed at the Rothamsted Experimental Station since 1955, and is also used by several soil scientists mainly within the Commonwealth.

The aim of this study was primarily, to compare the $\mathrm{pH}$ values of some soils determined in different liquids, particularly the use of $0.01 \mathrm{M} \mathrm{CaCl}_{2}$ as compared to water. The relationship between $\mathrm{pH}_{\mathrm{H}_{2} \mathrm{O}}$ and $\mathrm{pH}_{\mathrm{CaCl}_{2}}$ was examined statistically. Changes of $\mathrm{pH}$ due to different soil/liquid ratios, time required for equilibration and certain other factors affecting $\mathrm{pH}$ measurement in the laboratory were also studied. 


\section{Material and methods}

The 15 soil samples mainly used in this study were selected to represent various soil types and different acidity levels. In addition, 80 samples from a field experiment, P 62, are represented by three pooled samples giving the average of the different layers. These soils and some of the characteristics most closely affecting their $\mathrm{pH}$ are listed in Table 1. Further, a material consisting of 406 soil samples has been used for comparison of $\mathrm{pH}_{\mathrm{H}_{2} \mathrm{O}}$ and $\mathrm{pH}_{\mathrm{CaCl}_{2}}$ values.

All samples were air-dried and ground to $2 \mathrm{~mm}$. The methods used for characterization of the samples were as follows: The mechanical analyses were performed by the method of Soveri and HilpI (11). The organic carbon content was determined

Table 1. Soil samples

\begin{tabular}{|c|c|c|c|c|c|c|c|c|}
\hline \multirow[t]{2}{*}{ Sample } & \multirow[t]{2}{*}{ Soil type } & \multirow[t]{2}{*}{$\begin{array}{l}\text { Depth } \\
\mathrm{cm}\end{array}$} & \multicolumn{3}{|c|}{$\begin{array}{c}\text { Mechanical analysis } \\
\%\end{array}$} & \multirow[t]{2}{*}{$\begin{array}{c}\text { Org. C } \\
\%\end{array}$} & \multirow[t]{2}{*}{$\begin{array}{c}\text { CEC } \\
\text { me./100 g }\end{array}$} & \multirow[t]{2}{*}{ BS $\%$} \\
\hline & & & clay & silt & $\begin{array}{l}\text { fine } \\
\text { sand }\end{array}$ & & & \\
\hline Vi 4 a & fine sand & $0-20$ & 24 & 21 & 49 & 5.6 & 19.5 & 36 \\
\hline V 2 & clay loam & $0-20$ & 40 & 22 & 31 & 4.6 & 25.0 & 58 \\
\hline V 1 & clay loam & $0-20$ & 43 & 30 & 25 & 6.0 & 38.5 & 25 \\
\hline Vi 2 a & sandy clay & $0-20$ & 45 & 18 & 25 & 4.5 & 15.5 & 81 \\
\hline C 7 & sandy clay & $0-20$ & 47 & 14 & 35 & 3.5 & 25.0 & 92 \\
\hline C 6 & silty clay & $0-20$ & 47 & 34 & 18 & 1.3 & 22.5 & 64 \\
\hline $\mathrm{SC}_{\mathrm{p}}$ & Sphagnum-Carex-peat & $0-20$ & - & - & - & 48.3 & 82.0 & 23 \\
\hline $\mathrm{LC}_{\mathrm{p}}$ & Wood-Carex-peat & $0-20$ & - & - & - & 30.0 & 100.5 & 33 \\
\hline \multicolumn{9}{|l|}{ Profiles: } \\
\hline Vi 6 a & fine sand & $0-20$ & 29 & 19 & 41 & 3.6 & 18.5 & 30 \\
\hline $6 \mathrm{~b}$ & clay loam & $20-40$ & 42 & 28 & 28 & 2.6 & 20.0 & 20 \\
\hline $6 \mathrm{c}$ & silty clay & $50-60$ & 55 & 26 & 18 & 2.5 & 23.5 & 34 \\
\hline To 9 a & silt & $0-10$ & 12 & 67 & 20 & 1.7 & 11.5 & 61 \\
\hline $9 \mathrm{~b}$ & silty clay & $20-30$ & 35 & 59 & 6 & 1.1 & 16.0 & 97 \\
\hline $9 \mathrm{c}$ & silt & $40-50$ & 16 & 74 & 10 & 0.5 & 13.0 & 96 \\
\hline $9 \mathrm{~d}$ & silt & $60-70$ & 26 & 66 & 8 & 0.8 & 14.0 & 96 \\
\hline P 62 a & silty clay & $0-20$ & 30 & 56 & 13 & 3.1 & 20.8 & 76 \\
\hline b & silty clay & $45-55$ & 36 & 53 & 11 & 0.2 & 19.3 & 97 \\
\hline c & silty clay & $95-105$ & 38 & 56 & 6 & 0.3 & 19.5 & 97 \\
\hline
\end{tabular}

by a modified method of Walkley-Black. Cation exchange capacity (CEC) and base saturation percentage (BS \%) were determined by the method of TERÄSVUORI (13). Electrical conductance was measured in the 1: 2.5 soil/water suspension.

Generally, for the $\mathrm{pH}$ determinations $10 \mathrm{ml}$ samples of soil were placed in beakers and $25 \mathrm{ml}$ distilled water or $0.01 \mathrm{M} \mathrm{CaCl}_{2}$ added and the suspensions then stirred with a glass rod. Different soil/liquid rations are specified. After the varying periods of equilibration, $\mathrm{pH}$ was measured in freshly stirred suspension while moving the beaker gently, to get the immersed electrodes in different parts of the suspension. 
A Beckman Zeromatic pH meter with a standard glass and calomel electrode assembly was used. The buffers employed were $0.05 \mathrm{M}$ potassium biphtalate and Beckman 3581 buffer solution, their $\mathrm{pH}$ values 4.002 and 7.02 at $20^{\circ} \mathrm{C}$. respectively. The effect of variation in temperature was tried to keep as small as possible. The meter was checked during a series of measurements after every sixth reading with the buffer nearest to the $\mathrm{pH}$ value of the next sample. The $\mathrm{pH}$ value was recorded, when 2 successive readings did agree. Between measurements the electrodes were washed with distilled water. The $\mathrm{pH}$ values reported are means of duplicate or triplicate determinations made on separate days.

\section{The relationship between $p \mathrm{H}_{\mathrm{H}_{2} \mathrm{O}}$ and $p \mathrm{H}_{\mathrm{CaCl}_{2}}$}

A comparison of the $\mathrm{pH}$ values in Table 2, determined in water and $0.01 \mathrm{M}$ $\mathrm{CaCl}_{2}$ in the 1: 2.5 soil/liquid ratio and measured after $24 \mathrm{hrs}$, shows the lowering effect on $\mathrm{pH}$ of the neutral salt solution. Further examination reveals that the $\mathrm{pH}_{\mathrm{H}_{2} \mathrm{O}}$

Table 2. The $\mathrm{pH}$ values measured in water and $0.01 \mathrm{M} \mathrm{CaCl}_{2}$ and their difference

\begin{tabular}{|c|c|c|c|c|c|}
\hline Sample & \multirow{2}{*}{$\begin{array}{c}\mathrm{pH}_{\mathrm{H}_{2} \mathrm{O}} \\
4.60\end{array}$} & \multirow{2}{*}{$\begin{array}{c}\mathrm{pH}_{\mathrm{CaCl}_{2}} \\
\\
4.30\end{array}$} & \multirow{2}{*}{$\begin{array}{c}\text { Conductance } \\
\text { mmho./cm } \\
18^{\circ} \mathrm{C} \\
0.18\end{array}$} & \multirow{2}{*}{$\begin{array}{c}\begin{array}{c}\text { Difference } \mathrm{pH}_{\mathrm{H}_{2} \mathrm{O}} \\
\text { observed }\end{array} \\
0.30\end{array}$} & \multirow{2}{*}{$\begin{array}{c}\begin{array}{r}-\mathrm{pH}_{\mathrm{CaCl}_{2}} \\
\text { calculated }\end{array} \\
0.52\end{array}$} \\
\hline Vi 4 a & & & & & \\
\hline V 2 & 5.28 & 4.85 & 0.17 & 0.43 & 0.53 \\
\hline V 1 & 4.79 & 4.34 & 0.16 & 0.45 & 0.55 \\
\hline Vi 2 a & 5.46 & 4.85 & 0.10 & 0.61 & 0.65 \\
\hline C 7 & 6.11 & 5.75 & 0.22 & 0.36 & 0.47 \\
\hline C 6 & 5.42 & 4.86 & 0.11 & 0.56 & 0.63 \\
\hline $\mathrm{SCp}$ & 4.18 & 3.66 & 0.24 & 0.52 & 0.46 \\
\hline $\mathrm{LC}_{\mathrm{p}}$ & 4.30 & 4.06 & 0.27 & 0.24 & 0.44 \\
\hline Vi 6 a & 4.69 & 4.20 & 0.15 & 0.49 & 0.57 \\
\hline $6 \mathrm{~b}$ & 4.38 & 3.86 & 0.11 & 0.52 & 0.63 \\
\hline $6 \mathrm{c}$ & 4.47 & 4.03 & 0.22 & 0.44 & 0.49 \\
\hline To 9 a & 5.42 & 4.65 & 0.05 & 0.77 & 0.79 \\
\hline $9 \mathrm{~b}$ & 7.36 & 6.56 & 0.04 & 0.80 & 0.84 \\
\hline $9 \mathrm{c}$ & 7.24 & 6.45 & 0.03 & 0.79 & 0.88 \\
\hline $9 \mathrm{~d}$ & 7.28 & 6.48 & 0.04 & 0.80 & 0.84 \\
\hline
\end{tabular}

values reflect the soils' own salt content, of which the conductance measurements give an approximation. The difference between $\mathrm{pH}_{\mathrm{H}_{2} \mathrm{O}}$ and $\mathrm{pH}_{\mathrm{CaCl}_{2}}$ ranges from 0.24 to $0.80 \mathrm{pH}$ units, and these values correspond to the highest and lowest conductance in these soils. The profile To 9 a-d where the difference between the $\mathrm{pH}$ values is greatest, represents a leached-out silt soil with extremely low conductivity, indicating a nearly total lack of soluble salts especially in the deeper layers. The samples Vi 2 a and C 6 with low conductance accordingly show greater differences.

When both the conductance and the $\mathrm{pH}$ of a given soil/water suspension are known, the $\mathrm{pH}$ which this soil would have in $0.01 \mathrm{M} \mathrm{CaCl}_{2}$ suspension can approximately be calculated (12). The differences between $\mathrm{pH}_{\mathrm{H}_{2} \mathrm{O}}$ and calculated $\mathrm{pH}_{\mathrm{CaCl}_{2}}$ 
values are also presented in Table 2 . The measured and calculated differences agree fairly well in mineral soils. When a soil's own salt content is very low, the agreement seems to be closest.

While $\mathrm{pH}$ values measured in water are generally used, the question of the lowering effect of $0.01 \mathrm{M} \mathrm{CaCl}_{2}$ on the $\mathrm{pH}$ and the resulting difference from $\mathrm{pH}_{\mathrm{H}_{2} \mathrm{O}}$ values becomes of great practical interest. TERÄsvUORI (13) proposes that for agronomic purposes a correction factor could be added to $\mathrm{pH}_{\mathrm{CaCl}_{2}}$ values to bring them to the level of $\mathrm{pH}_{\mathrm{H}_{2} \mathrm{O}}$ that the farmers are accustomed to. On the basis of the mean electrolyte content of Finnish soils he estimates that this correction would be about $+0.40-+0.45 \mathrm{pH}$ units.

The actual relationship between $\mathrm{pH}_{\mathrm{H}_{2} \mathrm{O}}$ and $\mathrm{pH}_{\mathrm{CaCl}_{2}}$ values was studied on a larger unpublished material provided by Dr. Armi KaILA. The data concerning these soils are presented below with the mean values with the confidence limits at 95 per cent level. The soils were grouped on the basis of the texture and included both cultivated and virgin soils, from surface and deeper layers, cultivated surface soils predominating.

\begin{tabular}{|c|c|c|c|c|c|}
\hline Soil group & $\begin{array}{c}\text { Number } \\
\text { of } \\
\text { samples }\end{array}$ & $\begin{array}{c}\text { Mean } \\
\mathrm{pH}_{\mathbf{H}_{2} \mathbf{O}}\end{array}$ & $\begin{array}{c}\text { Mean } \\
\mathrm{pH}_{\mathrm{CaCl}_{2}}\end{array}$ & $\begin{array}{l}\text { Difference } \\
\text { Range }\end{array}$ & $\underset{\text { Mean }}{\mathrm{pH}} \mathrm{H}_{\mathrm{H}_{2} \mathrm{O}}-\mathrm{pH}_{\mathrm{CaCl}_{2}}$ \\
\hline Sand and finesand & 109 & $5.7 \pm 0.1$ & $5.2 \pm 0.1$ & 0.2 to 0.9 & $0.50 \pm 0.03$ \\
\hline Loam and silt $\quad \ldots \ldots \ldots \ldots$ & 103 & $5.8 \pm 0.1$ & $5.2 \pm 0.1$ & 0 to 1.1 & $0.54 \pm 0.04$ \\
\hline Clay $\ldots \ldots \ldots \ldots \ldots \ldots$ & 148 & $5.7 \pm 0.1$ & $5.2 \pm 0.1$ & 0.1 to 0.9 & $0.46 \pm 0.03$ \\
\hline Humus............... & 46 & $4.9 \pm 0.2$ & $4.4 \pm 0.2$ & 0.1 to 0.7 & $0.44 \pm 0.04$ \\
\hline All $\ldots \ldots \ldots \ldots \ldots \ldots$ & 406 & $5.7 \pm 0.1$ & $5.2 \pm 0.1$ & 0 to 1.1 & $0.49 \pm 0.02$ \\
\hline
\end{tabular}

Ranges of the $\mathrm{pH}$ values were relatively wide, owing to a few samples from virgin soils and deeper layers. The mean $\mathrm{pH}_{\mathrm{H}_{2} \mathrm{O}}$ values for the soil groups agreed with the average values observed in surface samples of the corresponding soil types over the country (3). The difference between $\mathrm{pH}_{\mathrm{H}_{2} \mathrm{O}}$ and $\mathrm{pH}_{\mathrm{CaCl}_{2}}$ values ranged from 0 to $1.1 \mathrm{pH}$ units and even the mean differences for the various soil groups ranged from 0.44 to 0.55 . According to these data, it does not seem advisable to use any correction factor to interpret $\mathrm{pH}_{\mathrm{CaCl}_{2}}$ values for agronomic services on a larger scale.

A scatter diagram, obtained by plotting the corresponding $\mathrm{pH}$ values showed a linear relationship between $\mathrm{pH}_{\mathrm{H}_{2} \mathrm{O}}$ and $\mathrm{pH}_{\mathrm{CaCl}_{2}}$. This has also been noted by Peaslee et al. (5). After a highly significant correlation was found, regression equations for the different soil groups were calculated. The relation between $\mathrm{pH}_{\mathrm{H}_{2} \mathrm{O}}$ and $\mathrm{pH}_{\mathrm{CaCl}_{2}}$ as expressed by a linear regression and positive correlation is presented below.

\begin{tabular}{|c|c|c|}
\hline Soil group & $\begin{array}{c}\text { Regression equation } \\
\mathrm{y}=\mathrm{pH}_{\mathrm{H}_{2} \mathrm{O}}, \mathbf{x}=\mathrm{pH}_{\mathrm{CaCl}_{2}}\end{array}$ & $\begin{array}{c}\text { Correlation } \\
\text { coefficient } \\
\mathrm{r}\end{array}$ \\
\hline Sand and finesand & $\mathrm{y}=0.81+0.94 \mathrm{x}$ & $0.965^{* * *}$ \\
\hline Loam and silt $\ldots$ & $\mathrm{y}=0.54+1.00 \mathrm{x}$ & $0.936^{* * *}$ \\
\hline Clay ........... & $y=0.70+0.96 x$ & $0.914^{* * *}$ \\
\hline Humus.......... & $y=0.80+0.92 x$ & $0.980^{* * *}$ \\
\hline All $\ldots \ldots \ldots$ & $\ldots y=0.65+0.97 x$ & $0.971 * * *$ \\
\hline
\end{tabular}


As was predictable, there was very slight correlation between $\mathrm{pH}_{\mathrm{H}_{2} \mathrm{O}}$ and the difference $\mathrm{pH}_{\mathrm{H}_{2} \mathrm{O}}-\mathrm{pH}_{\mathrm{CaCl}_{2}}$, since the latter depends largely on the soluble salt content of the soil and not on the $\mathrm{pH}$ level.

\section{The effect of soil/liquid ratio}

In this study the 1: 2.5 soil/liquid ratio on the volume basis has been employed, but $\mathrm{pH}$ values were also determined using 1: 5 and 1: 10 ratios, and the values compared. The resulting changes when the soil/liquid ratio was widened, did agree with the general rule that $\mathrm{pH}$ of an acid soil increases with dilution of the suspension. Most of the $\mathrm{pH}_{\mathrm{H}_{2} \mathrm{O}}$ values showed a fairly uniform increase of about $0.15 \mathrm{pH}$ units when the ratio was changed from 1: 2.5 to $1: 5$, and a further increase of the same order when the ratio was 1:10. However, dilution alone, in the absence of salts, may have no marked effect on $\mathrm{pH}_{\mathrm{H}_{2} \mathrm{O}}$, as noted by PURI and Asghar (6). The samples To $9 \mathrm{~b}$-d showed no change with dilution from 1: 5 to $1: 10$ and this could partly be caused by the lack of salts. According to Whitney and Gardner (14) the increase in $\mathrm{pH}$ on dilution is probably due primarily to dilution of the $\mathrm{CO}_{2}$ absorbed in the soil sample. Seatz and Peterson (10) explain it on the basis of the suspension effect.

The effect of changing soil/solution ratio in $\mathrm{CaCl}_{2}$ suspensions was slight, the differences between $\mathrm{pH}$ values in 1: 2.5 and 1: 5 suspensions being $\leqq 0.06 \mathrm{pH}$ units in 13 samples, and the others not exceeding 0.10 . A comparison of the 1: 2.5 and 1: 10 ratio values showed an average increase of $0.06 \mathrm{pH}$ units.

\section{The change in $p H$ values with time}

It is known that when a soil is suspended in water or salt solution, rapidly occurring exchange processes after a time reach a steady state. The slow processes, especially involving $\mathrm{Al}$ and $\mathrm{Si}$, will continue for a longer period towards the true equilibrium. The time required for the attainment of an equilibrium satisfactory for practical purposes was tried to decide on considering the magnitude of changes per period.

In addition to the 15 main samples, the change of $\mathrm{pH}$ values with time was also studied using 80 samples from a fairly uniform field experiment $\mathrm{P}$ 62. Half of the samples were from the surface layer, their $\mathrm{pH}_{\mathrm{H}_{2} \mathrm{O}}$ range being $5.20-5.78$, and half from the deeper layers $(50$ and $100 \mathrm{~cm}), \mathrm{pH}_{\mathrm{H}_{2} \mathrm{O}} 6.13-6.98$. The $\mathrm{pH}$ values were measured after 1, 2 and 24 hours, and the changes occurring during the second hour and from that time on to 24 hours were grouped, the group up to 0.02 representing the reproducibility of the $\mathrm{pH}$ meter. The results are in Table 3.

The $\mathrm{pH}$ values measured after 2 hours compared with the values after the first hour show small change in $\mathrm{pH}_{\mathrm{CaCl}_{2}}$ values. For the surface samples of $\mathrm{P} 62$, threefourths of the differences noted are $\leqq 0.05 \mathrm{pH}$ units. The $2-24$ hours interval shows even smaller changes, clearly indicating that a satisfactory equilibrium in 
Table 3. Distribution of the changes in $\mathrm{pH}$ with time

\begin{tabular}{|c|c|c|c|c|c|}
\hline & \multicolumn{4}{|c|}{ Change in $\mathrm{pH}$ units } \\
\hline & & $0-0.02$ & $0.03-0.05$ & $0.06-0.10$ & $>0.10$ \\
\hline & & \multicolumn{4}{|c|}{ Number of samples of various groups } \\
\hline \multicolumn{6}{|c|}{$\begin{array}{l}\mathrm{pH}_{\mathrm{H}_{2} \mathrm{O}} \\
\text { The } 15 \text { main samples }\end{array}$} \\
\hline $1-2$ hours & $\ldots \ldots \ldots \ldots \ldots$ & 6 & 5 & 3 & 1 \\
\hline $2-24$ & $\ldots \ldots \ldots \ldots$ & 9 & 1 & 3 & 2 \\
\hline \multicolumn{6}{|c|}{ P 62} \\
\hline \multicolumn{6}{|c|}{40 surface samples } \\
\hline $1-2$ hours & $\ldots \ldots \ldots \ldots \ldots$ & 12 & 7 & 14 & 7 \\
\hline $2-24$ & $\ldots \ldots \ldots \ldots \ldots$ & 11 & 14 & 10 & 5 \\
\hline \multicolumn{6}{|c|}{40 subsoil samples } \\
\hline $1-2$ hours & $\ldots \ldots \ldots \ldots$ & 11 & 9 & 18 & 2 \\
\hline $2-24$ & $\ldots \ldots \ldots \ldots$ & 12 & 6 & 17 & 5 \\
\hline \multicolumn{6}{|c|}{$\begin{array}{l}\mathrm{pH}_{\mathrm{CaCl}_{2}} \\
\text { The } 15 \text { main samples }\end{array}$} \\
\hline $1-2$ hours & $\ldots \ldots \ldots \ldots \ldots$ & 8 & 6 & 1 & \\
\hline $2-24$ & $\ldots \ldots \ldots \cdots \cdots$ & 10 & 3 & 2 & \\
\hline \multicolumn{6}{|l|}{ P 62} \\
\hline \multicolumn{6}{|c|}{40 surface samples } \\
\hline $1-2$ hours & $\ldots \ldots \ldots \ldots \ldots$ & 19 & 11 & 10 & \\
\hline $2-24$ & $\ldots \ldots \ldots \ldots \ldots$ & 26 & 8 & 6 & \\
\hline \multicolumn{6}{|c|}{40 subsoil samples } \\
\hline $1-2$ hours & $\ldots \ldots \ldots \ldots \ldots$ & 17 & 9 & 8 & 6 \\
\hline $2-24$ & $\ldots \ldots \ldots \ldots \ldots$ & 14 & 11 & 13 & 2 \\
\hline
\end{tabular}

most cases is essentially reached during the first $1-2$ hours period. For the 15 main soils the pattern is repeated. Only for subsoil samples differences greater than 0.1 $\mathrm{pH}$ units have been observed. The $\mathrm{pH}_{\mathrm{H}_{2} \mathrm{O}}$ values show a similar development, though the changes are less uniform and more often over $0.1 \mathrm{pH}$ units. According to DEAN and WALKER (1), for $\mathrm{pH}_{\mathrm{H}_{2} \mathrm{O}}$ the recommended contact period should not be over 12 hours, as during this time very little change in $\mathrm{pH}$ was found.

The direction of the change with time varied. For the surface samples of the $\mathrm{P}$ 62, a slight decrease in $\mathrm{pH}_{\mathrm{H}_{2} \mathrm{O}}$ values was noted with increasing period of contact from 2 to 24 hours, and a slight increase in $\mathrm{pH}_{\mathrm{CaCl}_{2}}$ values, both on the average well within bounds of reproducibility. For subsoils, the $\mathrm{pH}$ measured after 24 hours showed an average increase of 0.03 and $0.06 \mathrm{pH}$ units for $\mathrm{pH}_{\mathrm{H}_{2} \mathrm{O}}$ and $\mathrm{pH}_{\mathrm{CaCl}_{2}}$ values respectively, compared with the values measured after the first hour.

From the practical point of view, the constancy observed in $\mathrm{pH}_{\mathrm{CaCl}_{2}}$ values would mean that measurements can be made after a relatively short equilibration period of $1-2$ hours or the suspension can be left overnight, without significant difference. A short equilibration period would be preferable. 


\section{The suspension effect}

The difference in the $\mathrm{pH}$ determined in the supernatant liquid and in the suspension or sediment of a soil-water system is a well-known fact, but the nature of this suspension effect has from the beginning been a matter of controversy. It is attributed primarily to a liquid junction potential of the calomel electrode and to avoid this error in the measuring system the reference electrode should be in the supernatant liquid. If the system is in equilibrium the position of the glass electrode does not affect the result. If the equilibrium is not yet reached, RAUPACH (7) recommends immersing the glass electrode in the suspension.

Therefore, the usual practice of measuring soil $\mathrm{pH}$ in freshly stirred suspension involves the uncertainty of liquid junction potential. To examine the magnitude of the suspension effect, soil suspensions were prepared as usual in water and 0.01 $\mathrm{M} \mathrm{CaCl}_{2}$ in ratio 1 : 2.5 but doubling usual volumes to facilitate the handling and measuring. After settling overnight the supernatant liquid of $\mathrm{CaCl}_{2}$ suspensions was quite clear, but remained muddy in $\mathrm{H}_{2} \mathrm{O}$ suspensions. The $\mathrm{pH}$ values were measured first with both electrodes in the supernatant liquid, then in stirred suspension. The results are in Table 4 .

Table 4. The difference between $\mathrm{pH}$ values measured in supernatant solution and in suspension

\begin{tabular}{|c|c|c|c|c|}
\hline \multirow[t]{2}{*}{ Sample } & \multicolumn{2}{|c|}{$\mathrm{pH}_{\mathrm{H}_{2} \mathrm{O}}$} & \multicolumn{2}{|c|}{$\mathrm{pH}_{\mathrm{CaCl}_{2}}$} \\
\hline & $\begin{array}{l}\text { Super- } \\
\text { natant } \\
\text { liquid }\end{array}$ & $\begin{array}{l}\text { Supernatant } \\
\text { liquid minus } \\
\text { suspension }\end{array}$ & $\begin{array}{l}\text { Super- } \\
\text { natant } \\
\text { liquid }\end{array}$ & $\begin{array}{l}\text { Supernatant } \\
\text { liquid minus } \\
\text { suspension }\end{array}$ \\
\hline
\end{tabular}

\begin{tabular}{|c|c|c|c|c|c|}
\hline Vi & $4 a$ & 4.75 & 0.07 & 4.28 & 0.02 \\
\hline V & 2 & 5.46 & 0.11 & 4.95 & 0.05 \\
\hline V & 1 & 4.90 & 0.05 & 4.35 & 0.01 \\
\hline Vi : & 2 a & 5.55 & 0.03 & 4.95 & 0.09 \\
\hline C & 7 & 6.45 & 0.30 & 6.05 & 0.25 \\
\hline C & 6 & 5.60 & 0.08 & 5.00 & 0.10 \\
\hline $\mathrm{SC}_{\mathrm{p}}$ & & 4.30 & 0.06 & 3.70 & 0.02 \\
\hline $\mathrm{LC}_{\mathrm{p}}$ & & 4.45 & 0.09 & 4.10 & 0.03 \\
\hline Vi & $6 \mathrm{a}$ & 4.85 & 0.10 & 4.24 & 0.04 \\
\hline & $6 \mathrm{~b}$ & 4.52 & 0.07 & 3.93 & 0.03 \\
\hline & $6 \mathrm{c}$ & 4.57 & 0.02 & 4.15 & 0.07 \\
\hline To : & 9 a & 5.85 & 0.25 & 4.85 & 0.15 \\
\hline & $9 \mathrm{~b}$ & 6.99 & -0.49 & 6.50 & -0.12 \\
\hline & $9 \mathrm{c}$ & 6.90 & -0.42 & 6.45 & -0.05 \\
\hline & $9 \mathrm{~d}$ & 6.98 & -0.40 & 6.55 & -0.03 \\
\hline
\end{tabular}

In general, the $\mathrm{pH}$ of suspension is lower than that of the supernatant liquid, but some soils show a lower $\mathrm{pH}$ in the supernatant, as observed for the profile To 9 b-d sampless. This apparent negative suspension effect has been detected e.g. by PeEch et al. (5). 
These results emphasize the fact that even a small amount of salt reduces the suspension effect, and with the soil flocculated, makes the measurement in supernatant liquid easier. Even with careful handling the supernatant solution of the water suspension is apt to be disturbed.

\section{Notes on variation and accuracy}

To examine the variation of the results between replicates, one peat soil and three mineral soils representing different $\mathrm{pH}$ levels were chosen, and a series of 20 samples of each soil were taken. To test the accuracy of measuring by volume every $10 \mathrm{ml}$ sample was weighed. The agreement between replicates was within \pm 1 per cent for mineral soils, \pm 1.6 for the peat soil. Thus the convenient sampling on the volume basis seems to give satisfactory results on mineral soils.

The $\mathrm{pH}_{\mathrm{CaCl}_{2}}$ values of 20 replicates (in 1: 2.5 ratio, after $2 \mathrm{hrs}$.) showed a range of variation of $0.15 \mathrm{pH}$ units and the S.D. \pm 0.04 for the peat soil, and ranges of 0.8 and $0.12 \mathrm{pH}$ units and the S.D. \pm 0.03 for mineral soils.

When after a low $\mathrm{pH}$ value a considerably higher one was measured, a certain delay could be noticed before a stedy reading was obtained(7). No similar tendency was noted in the range of these soils when a higher $\mathrm{pH}$ was preceding a lower one. For easy and accurate measurements the soils may be arranged according to their $\mathrm{pH}$ values.

In this study attention has been focused on the factors most affecting the determination of soil $\mathrm{pH}$ in the laboratory. Yet the sampling and the sampling date, the pretreatment of the soil sample, the drying and the grinding have their effects. With all the factors involved, Russel (8) is of the opinion, that little information would be lost if one only measured the $\mathrm{pH}$ of field samples to the nearest 0.2 of a unit. Even in the most favourable circumstances, RAUPACH (7) considers no greater accuracy than $\pm \mathbf{0 . 1}$ unit for individual $\mathrm{pH}$ determinations justified.

Sum mary and conclusions

In the present paper the routine determination of soil $\mathrm{pH}$ in the laboratory was studied using a material of 15 soil samples of various kind and in addition, two larger soil groups, consisting of 80 and 406 samples respectively. In comparing the $\mathrm{pH}$ values determined in water and in $0.01 \mathrm{M} \mathrm{CaCl}_{2}$ suspensions, the latter proved to be almost independent of the soil/liquid ratio between 1: 2.5 and 1: 10, that markedly affected the $\mathrm{pH}_{\mathrm{H}_{2} \mathrm{O}}$ values. The change with time from the $\mathrm{pH}$ values measured after the first hour showed less variation in $\mathrm{CaCl}_{2}$ suspensions than in water suspensions; the constancy observed in $\mathrm{pH}_{\mathrm{CaCl}_{2}}$ values indicating that a relatively short equilibration period of $1-2$ hours would be sufficient. To sum up these results, the use of $0.01 \mathrm{M} \mathrm{CaCl}_{2}$ would mean easy and accurate measurements well suited to mass $\mathrm{pH}$ determinations. 
A linear relationship and a highly significant positive correlation was found between $\mathrm{pH}_{\mathrm{H}_{2} \mathrm{O}}$ and $\mathrm{pH}_{\mathrm{CaCl}_{2}}$ values in a material of 406 soil samples. The difference between the two values, which largely depends on the soils' own salt content, ranged from 0 to $1.1 \mathrm{pH}$ units, with the mean difference of 0.49 . Therefore, the suggested use of a constant correction factor to bring the $\mathrm{pH}_{\mathrm{CaCl}_{2}}$ values to the level of the $\mathrm{pH}$ measured in water, is not recommendable.

The main advantage of using $0.01 \mathrm{M} \mathrm{CaCl}_{2}$ would be the concealing of differences in salt content of a soil. The use of $\mathrm{pH}_{\mathrm{CaCl}_{2}}$ values would also offer new ways for getting more information about a soil's exchange capacities, as it provides the center point for TERÄSVUORI's (13) soil curve.

\section{REFERENCES}

(1) Dean, H. \& Walker, R. H. 1935. A comparison of glass and quinhydrone electrodes for deter mining the $\mathrm{pH}$ of some Iowa soils. III. The change in $\mathrm{pH}$ of the soil-water mixture with time. J. Am. Soc. Agr. 27: 585-595.

(2) Jenny, H. 1961. Reflections on the soil acidity merry-go-round. Soil Sci. Soc. Am. Proc. 25: 428432.

(3) KURKI, M. 1963. Suomen peltojen viljavuudesta vuosina 1955-1960 Viljavuuspalvelu Oy:ssä tehtyjen tutkimusten perusteella. Referat: Uber die Fruchtbarkeit des finnischen Ackerbodens auf Grund der in den Jahren 1955-1960 durchgeführten Bodenfruchtbarkeitsuntersuchungen. pp. 107. Helsinki.

(4) Peaslee, D. E., Anderson, C. A., Burns, G. R. \& Black, C. A. 1962. Estimation of relative value of phosphate rock and superphosphate to plants on different soils. Soil Sci. Soc. Am. Proc. 26: 566-570.

(5) Pefch, M., Olsen, R. A. \& Bolt, G. H. 1953. The significance of potentiometric measurements involving liquid junction in clay and soil suspensions. Ibid. 17: 214-218.

(6) Puri, A. N. \& Asghar, A. G. 1938. The influence of salts and soil-water ratio on pH value of soils. Soil Sci. 46: $249-257$.

(7) Raupach, M. 1954. The errors involved in pH determination in soils. Aust. J. Agric. Res. 5: 716 - 729.

(8) Russel, E. W. 1961. Soil conditions and plant growth. 9th ed. London, 688 p.

(9) Schofield, R. K. \& Taylor, A. W. 1955. The measurement of soil pH. Soil Sci. Soc. Am. Proc. 19: $164-167$.

(10) Seatz, L. F. \& Peterson, H. B. 1964. Acid, alkaline, saline and sodic soils. In Chemistry of the soil. ACS Monograph No. 160. pp. 292-319.

(11) SoverI, U. \& HILPI, E. 1952. Saviemme raekoostumuksen määrittämisestä areometrimenetelmällä. Abstract: The determination of the grain of clays by the areometric method. Tekn. aikak. 10: 224-226.

(12) TERĀSvuORI, A. 1930. Ưber die Bodenazidität mit besonderer Berücksichtigung des Elektrolytgehaltes der Bodenaufschlämmungen. Valt. maat. koet. julk. 29: 1-214. Helsinki.

(13) 1959. Uber das Bestimmen der Kationensorptionskapazität und des Basensăttigungsgrades des Bodens. Ibid. 175: 1-80.

(14) Whitney, R. S. \& Gardner, R. 1943. The effect of carbon dioxide on soil reaction. Soil Sci. 55: $127-141$. 


\title{
MAAN pH:N MÄÄRITTÄMISEST
}

\author{
Ritva Ryti
}

Helsingin Yliopiston maanviljelyskemian laitos, Pihlajamäki

Tutkimuksessa on verrattu maan $\mathrm{pH}$-arvoja määritettyinä vesi- ja $0.01 \mathrm{M} \mathrm{CaCl}_{2}$-lietoksessa, käyttäen päåasiallisesti 15 maanäytettä ja kahta suurempaa näyteryhmää, joihin kuului 80 ja 406 näytettä.

$\mathrm{CaCl}_{2}$-lietoksista mitatut $\mathrm{pH}$-arvot osoittautuivat käytännöllisesti katsoen riippumattomiksi maan ja liettämisnesteen suhteesta sen vaihdellessa $1: 2.5-1: 10$, kun taas liettämissuhteen väljentäminen huomattavasti vaikutti vesilietoksista mitattuihin arvoihin. Vuorokauden kuluessa tapahtuneet $\mathrm{pH}$-arvon muutokset $\mathrm{CaCl}_{2}$-lietoksissa olivat vähäisemmät kuin vesilietoksissa; mittausta varten riittävä tasapaino saavutettiin $\mathrm{CaCl}_{2}$-suspensioissa jo $1-2$ tunnin kuluessa. Mittaussysteemiin sisältyvä suspensiovaikutuksesta johtuva virhe pieneni huomattavasti suolalietoksessa. Laboratoriotyöskentelyn kannalta $\mathrm{CaCl}_{2}$-liuoksen käyttö osoittautui erityisesti hyvin soveltuvan sarjamäärityksiin.

Verrattaessa $\mathrm{pH}_{\mathrm{H}_{2} \mathrm{O}}$ - ja $\mathrm{pH}_{\mathrm{CaCl}_{2}}$ - arvoja 406 maanäytettä käsittävässä aineistossa, todettiin $\mathrm{CaCl}_{2}$-lietoksista mitattujen arvojen olevan keskimäärin $0.49 \mathrm{pH}$ yksikköä alempia kuin vesilietoksista mitatut; erojen vaihtelulaajuus oli $0-1.1$ yksikköä. Tästä syystä ehdotettu $\mathrm{pH}_{\mathrm{CaCl}_{2}}$-arvojen korottaminen vesilietoksessa mitattujen arvojen tasalle vakiotekijää käyttäen ei ole suositeltavissa.

Tärkein etu käytettäessä $\mathrm{CaCl}_{2}$-liuosta on, että se peittää maan oman suolapitoisuuden vaihtelusta aiheutuvat erot. $0.01 \mathrm{M} \mathrm{CaCl}_{2}$-lietoksessa mitattu $\mathrm{pH}$-arvo tarjoaa myöskin uusia mahdollisuuksia maan vaihto-ominaisuuksien selvittämiseen, koska se on TERÄSvUOREN (13) mmaan viivan, keskeinen piste. 